\title{
"High Risk" HPV Types Are Frequently Detected in Potentially Malignant and Malignant Oral Lesions, But Not in Normal Oral Mucosa
}

Martha Bouda, BSc, Vassilis G. Gorgoulis, M.D., Ph.D., Nikos G. Kastrinakis, BSc, MSc, Athina Giannoudis, BSc, Efthymia Tsoli, BSc, MPhil, Despina Danassi-Afentaki, M.D., Periklis Foukas, M.D., Aspasia Kyroudi, M.D., Ph.D., George Laskaris, M.D., Ph.D., C. Simon Herrington, M.D., Ph.D., Christos Kittas, M.D., Ph.D.

Department of Histology and Embryology, School of Medicine, University of Athens (MB, VGG, NGK, ET, $D D-A, A K, P F, C K)$, Athens, Greece; Department of Pathology, Royal Liverpool University Hospital (AG, CSH), Liverpool, United Kingdom; and Department of Dermatology, Syngros Hospital, Athens, Greece

Studies on the involvement of the human papillomavirus (HPV) in initiation and progression of oral neoplasia have generated conflicting results. The observed discrepancy is attributable mainly to the varying sensitivity of the applied methodologies and to epidemiologic factors of the examined patient groups. To evaluate the role of HPV in oral carcinogenesis, we analyzed 53 potentially neoplastic and neoplastic oral lesions consisting of 29 cases of hyperplasia, 5 cases of dysplasia, and 19 cases of squamous cell carcinomas, as well as 16 oral specimens derived from healthy individuals. A highly sensitive nested polymerase chain reaction (PCR) assay was used, along with type-specific PCR, restriction fragment length polymorphism analysis, dot blotting, and nonisotopic in situ hybridization. Nested PCR revealed the presence of HPV DNA in 48 of the 53 $(91 \%)$ pathologic samples analyzed, whereas none $(0 \%)$ of the normal specimens was found to be infected. Positivity for HPV was independent of histology and the smoking habits of the analyzed group of patients. At least one "high risk" type, such as HPV 16, 18, and 33, was detected by type-specific PCR in 47 (98\%) infected specimens, whereas only 1 (2\%) squamous cell carcinoma was solely infected by a "low risk" type (HPV 6). HPV 16 was the prevailing viral type, being present in $71 \%$ of infected cases. Single HPV 16 and HPV 18 infections were confirmed by restriction fragment length polymorphism. HPV 58 was detected by dot blotting in three hyperplastic lesions. HPV positivity and genotyping

Copyright () 2000 by The United States and Canadian Academy of Pathology, Inc.

VOL. 13, NO. 6, P. 644, 2000 Printed in the U.S.A

Date of acceptance: December 10, 1999.

Address reprint requests to: Gorgoulis Vassilis, Antaiou 53 str., Lamprini, Ano Patisia, Athens, Greece, Gr-11146; e-mail: histoclub@ath.forthnet.gr; fax: 30-1-779035. were further confirmed, and the physical status of this virus was evaluated by nonisotopic in situ hybridization. Diffuse and punctate signals, indicative of the episomal and integrative pattern of HPV infection, were observed for low- and high-risk types, respectively. Our findings are suggestive of an early involvement of high-risk HPV types in oral carcinogenesis.

KEY WORDS: Human papillomavirus, Oral carcinoma, Oral dysplasia, Oral mucosa.

Mod Pathol 2000;13(6):644-653

Cancer of the oral cavity is the sixth most common malignancy in developed countries, representing almost 3\% of malignant tumors (1). In India and other regions of southeast Asia, it is the predominant malignancy, accounting for up to $50 \%$ of all cancers (2). This high incidence of oral cancer is attributable mainly to the habit of tobacco chewing and, secondly, to alcohol and betel quid consumption (3). However, that a large part of the population develops oral cancer without exposure to these risk factors suggests that additional causes, such as genetic predisposition, diet, and viral agents, may participate in oral carcinogenesis (4). Viruses that have been implicated in oral neoplasias are Epstein-Barr virus, human herpesvirus 8, human cytomegalovirus, and, particularly, human papillomaviruses (HPVs) $(5,6)$.

HPV is a small, epitheliotropic, nonenveloped DNA virus. The HPV genome consists of 7200 to 8000 base pairs of closed-circular double-stranded DNA, containing up to 10 open reading frames. HPV belongs to a large family of viruses, the papova viridae, and thus far, more than a 100 different types have been identified in humans. Some of these types, such as $16,18,33$, and 58 , seem to play 
a role in the development of certain human tumors and are characterized as "high risk" types (7). Squamous cell malignant lesions of the cervix are infected mainly by high-risk viral types (8), whereas other organs, such as the larynx, are infected by a wide range of HPV types with varying tumorigenic potential $(7,9)$.

The presence of HPV genome in oral mucosa has been reported with various percentages and genotyping patterns (Table 1). Furthermore, most of the existing reports have selectively examined certain proliferative conditions of the oral cavity. To gain further insight on the involvement of the virus in carcinogenesis of the oral cavity, we comprehensively investigated HPV infection in 53 oral lesions, representing the whole spectrum of potentially neoplastic and neoplastic stages. The presence of HPV was also examined in 16 oral specimens derived from a group of healthy individuals. The experimental procedure consisted of a combination of techniques with the highest levels of sensitivity and specificity available. To our knowledge, this is the first study to examine HPV infection in oral hyperplasias, dysplasias, and squamous cell carcinomas (SqCCs), as well as in normal oral mucosa, by nested polymerase chain reaction (NPCR), typespecific PCR (TS-PCR), restriction fragment length polymorphism (RFLP) analysis, dot blotting (DB), and nonisotopic in situ hybridization (NISH).

\section{MATERIALS AND METHODS}

\section{Samples}

\section{Preneoplastic and neoplastic oral specimens}

Fifty-three archival, formalin-fixed, paraffinembedded oral specimens consisting of 29 hyperplasias, 5 dysplasias, and 19 SqCCs were obtained from the routine files of the Department of Dermatology, Syngros Hospital, Athens, Greece. All samples were biopsies and surgical specimens derived from the cheeks (22 cases), tongue (13 cases), alveolar mucosa (7 cases), gingiva (5 cases), lips (3 cases), palate ( 1 case), modiolus ( 1 case), and floor of the mouth (1 case). Thirty-one specimens were derived from male patients, and 22 were derived from female patients. The age of patients ranged from 27 to 84 years, with a mean age of 52.7 years. Thirty-eight samples (71.7\%) were derived from heavy smokers ( $>20$ cigarettes per day), and the remaining 15 samples (28.3\%) were derived from nonsmokers. Cancerous lesions were classified into poorly differentiated (one case), moderately differentiated (seven cases), well-differentiated (seven cases), and in situ carcinomas (three cases), according to Smith and Pindborgs' criteria (46) (Table 2).

\section{Normal oral specimens}

Sixteen cheek and tongue cytologic scrapes were obtained from a group of healthy subjects, consisting of 6 men and 10 women. Ages ranged from 24 to 65 years, with a mean age of 48.3 years. Five specimens $(31.3 \%)$ were derived from heavy smokers, and $11(68.7 \%)$ were derived from nonsmokers (Table 2).

\section{Experimental Procedure}

HPV genomic DNA was detected with a highly sensitive NPCR assay. To avoid false-negative results due to low DNA yield or low number of viral copies, extracted DNA integrity was confirmed by amplifying a 523-bp fragment of p53 exons 5-6, which is larger than the HPV fragments obtained by the PCR (9). In the first step of the NPCR assay, we used the degenerate L1 consensus primers MY09 and MY11 (47), which provide a sensitivity comparable to that of Southern blotting (1 viral copy per $10^{2}$ cells) (48). The second step of the assay was performed using the nested consensus primers GP5+/GP6+, which detect a broader spectrum of viral types than the "first-generation" GP5/GP6 primers and present the highest available sensitivity compared with any single technique (1 HPV copy per $10^{4}$ to $10^{5}$ cells) $(49,50)$. Positive NPCR samples were analyzed by TS-PCR with primers designed for the detection of HPV types $6,11,16$, 18, 31, and 33 (47). Samples infected solely by HPV 16 or HPV 18 were further analyzed by RFLP, because specimens with coinfections present an indefinite pattern in RFLP assays (51). Confirmation of NPCR results and detection of HPV 58 were carried out by DB assay (52-54). Finally, the physical status of the virus in infected specimens was investigated by NISH.

\section{DNA extraction}

Analysis of preneoplastic and neoplastic specimens was performed on six adjacent $5-\mu \mathrm{m}$ sections of each paraffin embedded tissue, with the first section being stained with hematoxylin and eosin to visualize the extent of the abnormal cells. The remaining slices were collected in a sterile $1.5-\mathrm{mL}$ microcentrifuge tube. DNA was extracted by a method generating high-quality and high-quantity DNA from paraffin-embedded tissues, as previously described (55). Normal specimens were initially placed in 2-mL neutral phosphate buffered saline in sterile 5-mL centrifuge tubes. Samples were centrifuged at $2000 \mathrm{rpm}$ for $15 \mathrm{~min}$, and DNA was extracted from the collected cell pellets after the QIAamp DNA Extraction procedure (QIAGEN; BioAnalytica, Athens, Greece). To avoid crosscontamination at any step of the procedure, paraffin-embedded compounds were cut between 


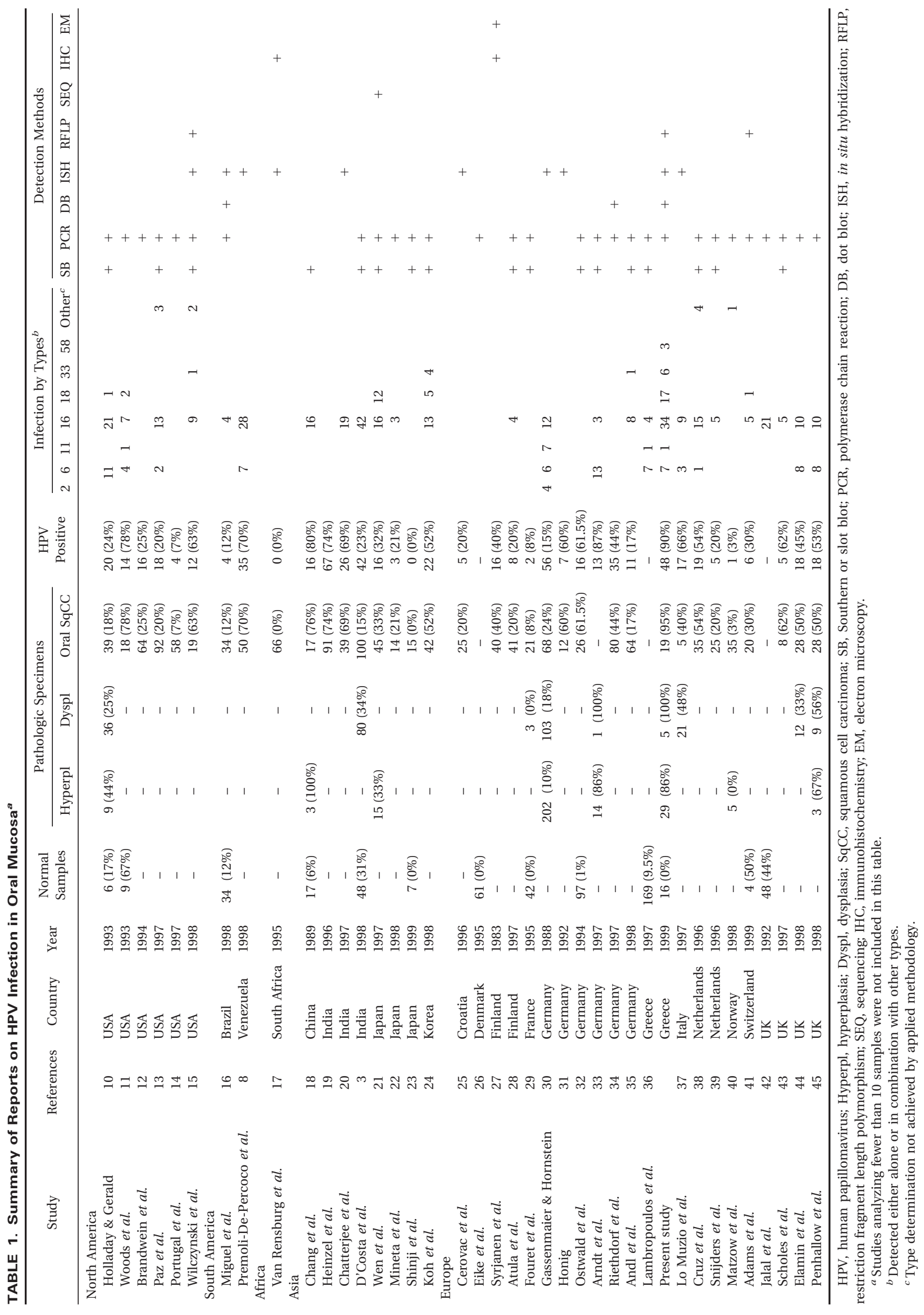


TABLE 2. Summary of Clinicopathologic Data and HPV Infection Results in Hyperplastic, Dysplastic, and Cancerous Lesions and in Normal Specimens

\begin{tabular}{|c|c|c|c|c|c|c|c|}
\hline Sample No. & Sex & Age & Smoking & Site & Histology & HPV Infection & Viral Type \\
\hline \multicolumn{8}{|c|}{ Hyperplastic, Dysplastic, and Cancerous Lesions } \\
\hline 1 & $\mathrm{~F}$ & 45 & + & Alveolar mucosa & Hyperplasia & + & 16 \\
\hline 2 & $\mathrm{M}$ & 75 & - & Alveolar mucosa & Hyperplasia & + & 16 \\
\hline 3 & $\mathrm{~F}$ & 40 & + & Alveolar mucosa & Hyperplasia & + & 18 \\
\hline 4 & M & 37 & + & Alveolar mucosa & Hyperplasia & - & - \\
\hline 5 & $\mathrm{M}$ & 44 & + & Cheek & Hyperplasia & + & 16 \\
\hline 6 & $\mathrm{M}$ & 50 & + & Cheek & Hyperplasia & + & 16 \\
\hline 7 & $\mathrm{~F}$ & 57 & - & Cheek & Hyperplasia & + & 18 \\
\hline 8 & $\mathrm{M}$ & 27 & + & Cheek & Hyperplasia & + & 16 \\
\hline 9 & $\mathrm{M}$ & 39 & + & Cheek & Hyperplasia & + & 33 \\
\hline 10 & M & 52 & + & Cheek & Hyperplasia & + & 16 \\
\hline 11 & M & 52 & + & Cheek & Hyperplasia & + & 16 \\
\hline 12 & $\mathrm{~F}$ & 36 & + & Cheek & Hyperplasia & + & $6,16,58$ \\
\hline 13 & M & 53 & + & Cheek & Hyperplasia & + & $6,16,58$ \\
\hline 14 & M & 48 & + & Cheek & Hyperplasia & + & 16 \\
\hline 15 & $\mathrm{M}$ & 57 & + & Cheek & Hyperplasia & - & - \\
\hline 16 & $\mathrm{M}$ & 41 & + & Cheek & Hyperplasia & + & $6,16,58$ \\
\hline 17 & $\mathrm{M}$ & 46 & + & Cheek & Hyperplasia & + & 16 \\
\hline 18 & M & 36 & + & Cheek & Hyperplasia & - & - \\
\hline 19 & $\mathrm{~F}$ & 45 & + & Floor of mouth & Hyperplasia & + & 18 \\
\hline 20 & $\mathrm{~F}$ & 55 & - & Gingiva & Hyperplasia & + & 16 \\
\hline 21 & $\mathrm{~F}$ & 47 & + & Gingiva & Hyperplasia & + & 18,33 \\
\hline 22 & M & 37 & + & Gingiva & Hyperplasia & + & 18 \\
\hline 23 & $\mathrm{~F}$ & 53 & + & Gingiva & Hyperplasia & + & 18 \\
\hline 24 & M & 40 & - & Modiolus & Hyperplasia & + & 16 \\
\hline 25 & $\mathrm{~F}$ & 34 & + & Palate & Hyperplasia & - & - \\
\hline 26 & $\mathrm{~F}$ & 53 & - & Tongue & Hyperplasia & + & $6,16,18$ \\
\hline 27 & $\mathrm{~F}$ & 55 & - & Tongue & Hyperplasia & + & 16,18 \\
\hline 28 & $\mathrm{~F}$ & 51 & + & Tongue & Hyperplasia & + & 16 \\
\hline 29 & $\mathrm{M}$ & 56 & + & Tongue & Hyperplasia & + & $6,16,33$ \\
\hline 30 & $\mathrm{~F}$ & 45 & - & Cheek & Dysplasia & + & 18 \\
\hline 31 & $\mathrm{M}$ & 63 & - & Cheek & Dysplasia & + & $6,11,16,18,31,33$ \\
\hline 32 & $\mathrm{M}$ & 62 & - & Cheek & Dysplasia & + & $16,18,33$ \\
\hline 33 & $\mathrm{M}$ & 64 & - & Lip & Dysplasia & + & 18 \\
\hline 34 & $\mathrm{~F}$ & 42 & + & Tongue & Dysplasia & + & 16 \\
\hline 35 & $\mathrm{~F}$ & 71 & + & Alveolar mucosa & $\mathrm{SqCC}(\mathrm{MD})$ & + & 16 \\
\hline 36 & M & 65 & + & Alveolar mucosa & SqCC (WD) & - & - \\
\hline 37 & M & 56 & + & Alveolar mucosa & SqCC (ISC) & + & 18 \\
\hline 38 & $\mathrm{M}$ & 46 & + & Cheek & SqCC (MD) & + & 16 \\
\hline 39 & $\mathrm{~F}$ & 68 & + & Cheek & SqCC (MD) & + & 16 \\
\hline 40 & $\mathrm{M}$ & 59 & - & Cheek & SqCC (MD) & + & 16 \\
\hline 41 & $\mathrm{~F}$ & 67 & + & Cheek & SqCC (WD) & + & 16 \\
\hline 42 & M & 62 & + & Cheek & SqCC (WD) & + & 6 \\
\hline 43 & M & 80 & + & Gingiva & SqCC (WD) & + & 16 \\
\hline 44 & $\mathrm{M}$ & 54 & + & Lip & SqCC (ISC) & + & 16 \\
\hline 45 & $\mathrm{M}$ & 64 & - & Lip & SqCC (WD) & + & 16 \\
\hline 46 & $\mathrm{~F}$ & 77 & - & Tongue & SqCC (WD) & + & 16,18 \\
\hline 47 & $\mathrm{~F}$ & 50 & + & Tongue & SqCC (ISC) & + & 18 \\
\hline 48 & M & 29 & + & Tongue & SqCC (MD) & + & 18 \\
\hline 49 & M & 41 & - & Tongue & SqCC (WD) & + & 16,33 \\
\hline 50 & $\mathrm{~F}$ & 84 & - & Tongue & SqCC (PD) & + & 16 \\
\hline 51 & $\mathrm{~F}$ & 57 & + & Tongue & SqCC (MD) & + & 16 \\
\hline 52 & $\mathrm{~F}$ & 84 & + & Tongue & SqCC (WD) & + & 18 \\
\hline 53 & M & 53 & + & Tongue & SqCC (MD) & + & 16 \\
\hline \multicolumn{8}{|c|}{ Normal Specimens } \\
\hline 1 & M & 24 & + & Cheek-tongue & - & - & - \\
\hline 2 & $\mathrm{M}$ & 35 & + & Cheek-tongue & - & - & - \\
\hline 3 & $\mathrm{M}$ & 48 & - & Cheek-tongue & - & - & - \\
\hline 4 & $\mathrm{M}$ & 49 & + & Cheek-tongue & - & - & - \\
\hline 5 & $\mathrm{M}$ & 63 & + & Cheek-tongue & - & - & - \\
\hline 6 & $\mathrm{M}$ & 65 & + & Cheek-tongue & - & - & - \\
\hline 7 & $\mathrm{~F}$ & 37 & - & Cheek-tongue & - & - & - \\
\hline 8 & $\mathrm{~F}$ & 40 & - & Cheek-tongue & - & - & - \\
\hline 9 & $\mathrm{~F}$ & 43 & - & Cheek-tongue & - & - & - \\
\hline 10 & $\mathrm{~F}$ & 44 & - & Cheek-tongue & - & - & - \\
\hline 11 & $\mathrm{~F}$ & 44 & - & Cheek-tongue & - & - & - \\
\hline 12 & $\mathrm{~F}$ & 50 & - & Cheek-tongue & - & - & - \\
\hline 13 & $\mathrm{~F}$ & 52 & - & Cheek-tongue & - & - & - \\
\hline 14 & $\mathrm{~F}$ & 55 & - & Cheek-tongue & - & - & - \\
\hline 15 & $\mathrm{~F}$ & 61 & - & Cheek-tongue & - & - & - \\
\hline 16 & $\mathrm{~F}$ & 63 & - & Cheek-tongue & - & - & - \\
\hline
\end{tabular}

HPV typing results are based on type-specific analysis, except for the specimens infected by HPV 58, which were examined by dot blot assay.

HPV, human papillomavirus; F, female; M, male; PD, poorly differentiated; MD, moderately differentiated; WD, well differentiated; ISC, in situ carcinoma. 
samples and were subsequently subjected to DNA extraction and PCR analysis.

\section{$H P V$-positive and -negative controls}

Control samples were selected as previously described (9). Briefly, cell lines CasKi and SiHa served as positive controls for HPV 16, HeLa for HPV 18, positive cervical warts for HPV 6 and 11, and cervical SqCCs for HPV 31, 33, and 58. Cell line K562 was used as negative control (56).

\section{PCR analysis}

Primers. Detection of HPV sequences was performed by two sets of consensus primers, MY09/ MY11 and GP5+/GP6+, which amplify a 448-bp and an internal 138-bp region, respectively, in the highly conserved L1 HPV gene $(47,50)$. Positive specimens were analyzed by TS-PCR for HPV types $6,11,16,18,31$, and 33 infection, as previously described (Fig. 1) (9).

$\boldsymbol{P C R}$. Amplifications were performed in a DNAfree room with DNA-free equipment to minimize the risk of contamination. Furthermore, negative controls of water were included between samples. DNA was transferred to the PCR buffer with aerosol-resistant pipette tips. The thermal profiles used were described in a previous study (9). After amplification, the reaction products were electrophoresed on $2 \%$ agarose and visualized by ethidium bromide staining (Fig. 1).

\section{RFLP analysis}

Single HPV 16 and HPV 18 infections were confirmed by RFLP using the following procedure: 25 $\mu \mathrm{L}$ MY09/MY11 PCR products were incubated overnight at $37^{\circ} \mathrm{C}$ with $0.5 \mu \mathrm{l} \mathrm{HaeIII}(20 \mathrm{u} / \mathrm{mL}), 0.5 \mu \mathrm{l}$ RsaI $(20 \mathrm{u} / \mathrm{mL})$, and $0.5 \mu \mathrm{l}$ Pst $(20 \mathrm{u} / \mathrm{mL})$ (Biolabs, BioLine, Athens, Greece) in a $0.5-\mathrm{mL}$ microcentrifuge tube. Digestion products were electrophoresed at $110 \mathrm{~V}$ for $90 \mathrm{~min}$ on 3\% MetaPhor agarose (FMC BioProducts, BioAnalytica) and evaluated according to the patterns reported by Lungu et al. (Fig. 1) (51).

\section{Dot blotting}

Infected specimens, which were identified by the NPCR assay, were further analyzed by DB, using type-specific oligomer probes $(52-54,57)$. NPCR products were diluted $1: 10$ and denatured for 10 min at $95^{\circ} \mathrm{C}$. One microliter of the denatured DNA was applied on the nylon membrane and placed under ultraviolet light for $3 \mathrm{~min}$, followed by baking at $80^{\circ} \mathrm{C}$ for 1 to $2 \mathrm{~h}$. The membranes were placed into prehybridization buffer $(0.02 \%$ sodium dodecyl sulfate, $1 \mathrm{~g}$ blocking reagent in $2 \times$ standard saline citrate) for $1 \mathrm{~h}$ at $55^{\circ} \mathrm{C}$ and hybridized overnight at the same temperature using individual 5'digoxige-
A.

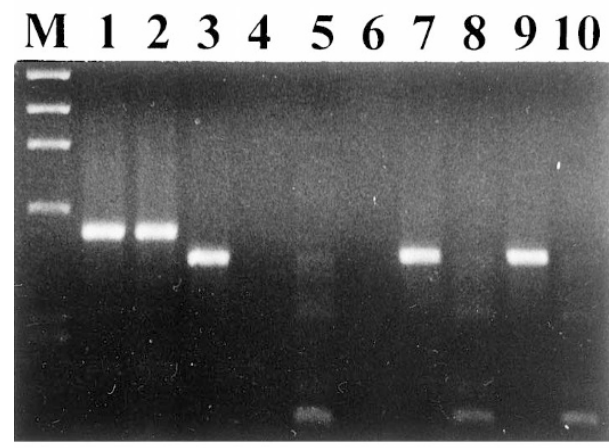

\section{B.}
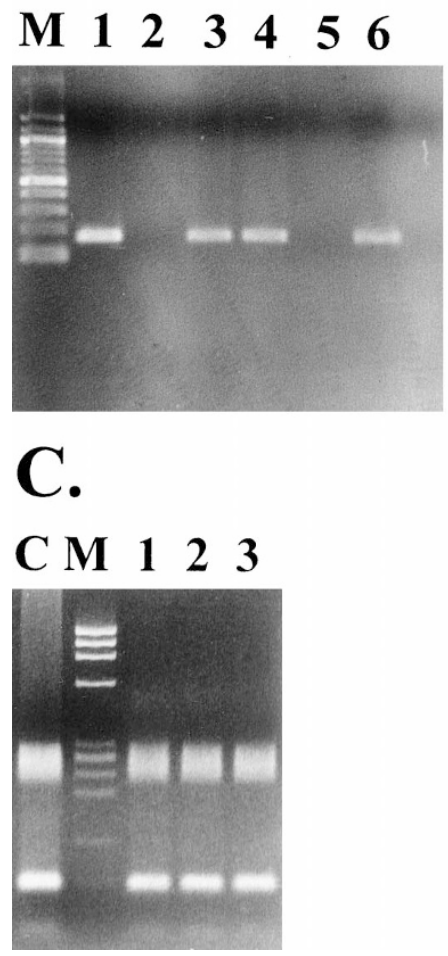

FIGURE 1. Representative human papillomavirus (HPV) nested polymerase chain reaction (NPCR) and type-specific PCR products, as well as restriction fragment length polymorphism digestion products. DNA samples were electrophoresed on 2\% agarose and 3\% MetaPhor agarose, respectively, and viewed by ethidium bromide staining. A, amplification products with consensus HPV primers. M, $\Phi \times 174$ /HaeIII DNA marker; lanes 1 to 2, 523-bp p53 gene amplified fragment from two specimens; lane 3, first-step NPCR HPV-positive control (448 bp); lane 4, HPV-negative control; lane 5, second-step NPCR HPV-positive control (138 bp); lane 6, HPV-negative control; lanes 7 to 10, alternating first-step and second-step NPCR products from two HPV-positive specimens. B, amplification products with type-specific PCR primers. M, 100-bp DNA marker; lane 1, HPV 16-positive control (172 bp); lane 2, HPV-negative control; lane 3, HPV 16-positive specimen; lane 4, HPV 18-positive control (172 bp); lane 5, HPV-negative control; lane 6, HPV 18-positive specimen. C, representative restriction fragment length polymorphism of specimens with single HPV 16 infections. C, HPV 16positive control; M, $\Phi \times 174$ /HaeIII DNA marker; lanes 2 to 4, HPV 16positive specimens.

nin labeled oligonucleotide probes. Hybridization membranes were washed in posthybridization buffer $(0.1 \%$ sodium dodecyl sulfate in $2 \times$ standard 
saline citrate) three times for $10 \mathrm{~min}$ at $55^{\circ} \mathrm{C}$ and in blocking solution $(0.5 \%$ Tween $20,1 \%$ blocking reagent in $1 \times$ alkaline phosphatase buffer [AP] 7.5) for $45 \mathrm{~min}$ at room temperature. Signal was detected using antidigoxigenin-alkaline phosphatase conjugate diluted 1:5000 in blocking solution for 30 min. Finally, the membranes were washed in blocking solution $1 \times$ AP $7.5(0.1 \mathrm{M}$ Tris, $0.1 \mathrm{M} \mathrm{NaCl} \mathrm{pH}$ 7.5, and $10 \mathrm{mM} \mathrm{MgCl}_{2}$ ) three times for $5 \mathrm{~min}$ and $1 \times$ AP 9.6 (0.1 Tris, $0.1 \mathrm{M} \mathrm{NaCl} \mathrm{pH} \mathrm{9.6,} \mathrm{and} 10 \mathrm{~mm}$ $\mathrm{MgCl}_{2}$ ) and developed using nitroblue tetrazolium/ bromo-chloro-indolyl phosphate in AP 9.6, up to $16 \mathrm{~h}$. Water blank PCR products were used as negative controls (Fig. 2).

\section{Nonisotopic in situ hybridization}

Hybridization, labeling, and evaluation were performed as previously described (9). In an additional signal-enhancing step, labeling by biotinyltyramide was applied, according to the manufacturer's directions (TSA-Indirect, NENTM Life Science Products, AlterChem, Athens, Greece). Visualization was carried out using diaminobenzidine tetrahydrochloride (Sigma Hellois, Athens, Greece) (Fig. 3).

\section{Statistical analysis}

$\chi^{2}$ tests with Yate's correction were performed using the Microstat software package (Ecosoft, Inc., Athens, Greece). Two-tailed Fisher's exact test was used when the samples in any cell were fewer than 5. $P$ values lower than 0.05 were considered significant.

\section{RESULTS}

NPCR analysis detected the presence of HPV genome in 48 of $53(90.6 \%)$ pathologic specimens examined. In contrast, none $(0 \%)$ of the 16 normal samples were found to be infected (Table 2). Of the

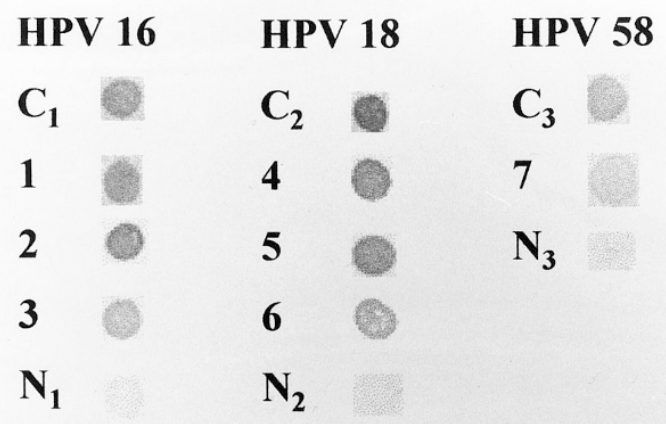

FIGURE 2. Representative dot blotting of type-specific polymerase chain reaction products for HPV 16,18 , and $58 . \mathrm{C}_{1}, \mathrm{C}_{2}$, and $\mathrm{C}_{3}$, positive controls for human papillomavirus (HPV) 16,18 , and 58, respectively. 1 to 3, HPV 16-positive cases; 4 to 6, HPV 18-positive cases; 7, HPV 58positive case; $\mathrm{N}_{1}, \mathrm{~N}_{2}$, and $\mathrm{N}_{3}$, negative controls for HPV 16, 18, and 58, respectively.
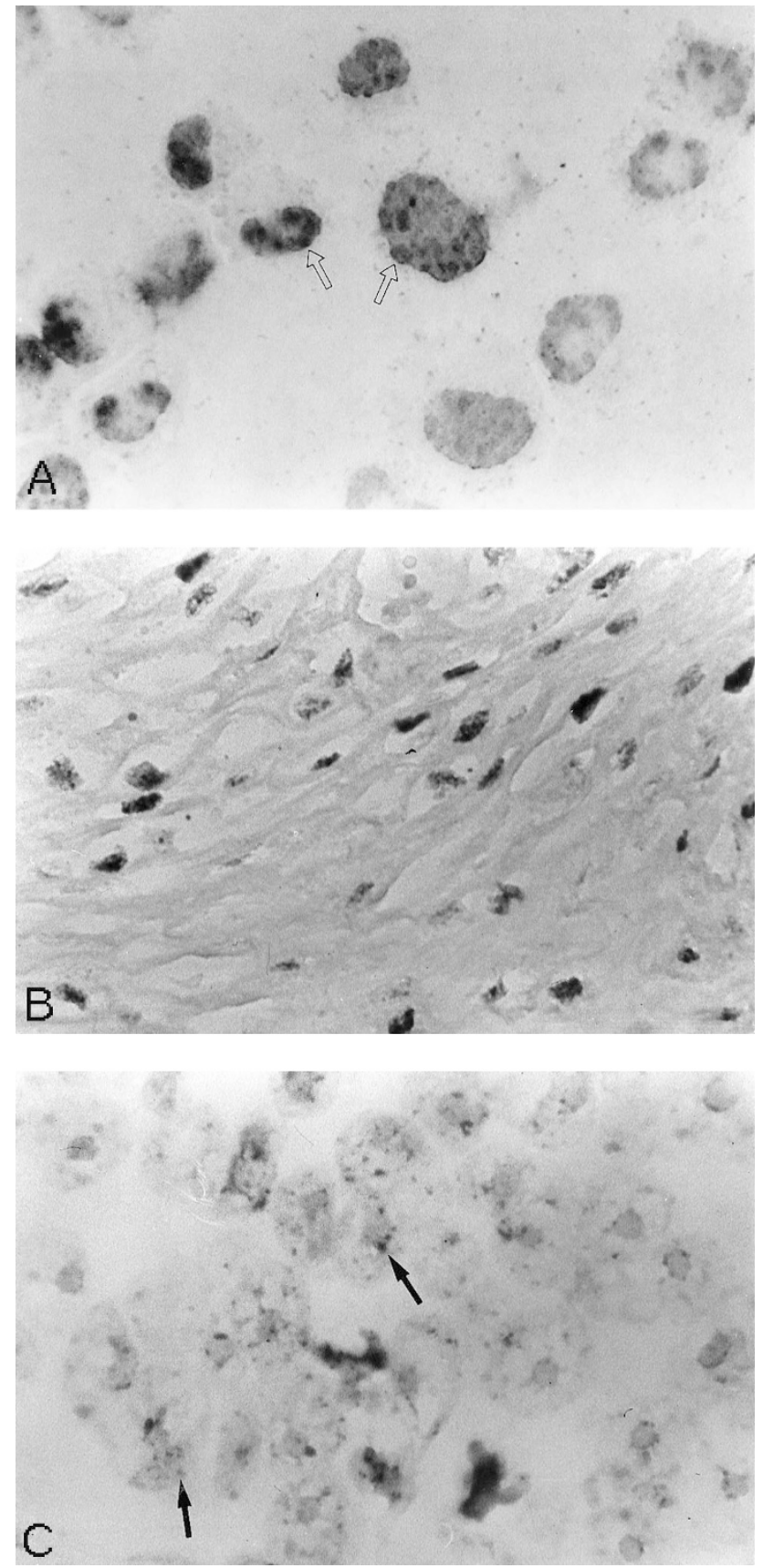

FIGURE 3. Representative nonisotopic in situ hybridization analysis. A, punctate (type 2) signal in Caski cells (arrows). B, diffuse (type 1) in an oral hyperplasia infected by human papillomavirus 6 . C, punctate (type 2) signal in an oral squamous cell carcinoma infected by human papillomavirus 16 (arrows) (original magnification, $\times 1000$ ).

Diaminobenzidine used as chromogen.

positive specimens, $34(70.8 \%)$ were identified by the first step and $14(29.2 \%)$ by the second step of the NPCR assay. This finding is suggestive of a viral load exceeding one copy per $10^{2}$ cells in the former samples (48). HPV was detected in 25 of 29 hyperplasias (86.2\%), 5 of 5 dysplasias (100\%), and 18 of 19 SqCCs $(94.7 \%)$. There was no correlation between HPV infection, histology $(P=.46)$, and classic HPV changes. Positivity for HPV was also independent of cancer differentiation $(P=.72)$. 
HPV genotyping was performed by TS-PCR and DB. All infected specimens identified by NPCR were also positive by TS-PCR, which indicates that the number of viral DNA copies was always higher than one per $10^{3}$ cells (48). Single HPV 6, 16, 18, and 33 infections were detected in 1 (2.1\%), 24 (50.0\%), 11 (22.9\%), and $1(2.1 \%)$ positive samples, respectively. Coinfections by types 6/16, 16/18, 16/33, 18/33, $16 / 18 / 33,6 / 16 / 33,6 / 16 / 18$, and $6 / 11 / 16 / 18 / 31 / 33$ were revealed in $3(6.3 \%), 2(4.2 \%), 1$ (2.1\%), 1 (2.1\%), 1 (2.1\%), 1 (2.1\%), 1 (2.1\%), and $1(2.1 \%)$ positive lesions, respectively (Table 2). At least one high-risk type was detected in $47(98.1 \%)$ infected specimens, with only 1 SqCC (1.9\%) being infected solely by a low-risk viral type (HPV 6). HPV 16 was the prevailing type, being present in 34 (70.8\%) infected cases either alone or in combination with other viral types. Single HPV 16 and HPV 18 infections were confirmed by RFLP analysis (Fig. 1). No association was observed between HPV typing and histology $(P=.14)$. DB results (Fig. 2) were in agreement with those obtained by TS-PCR. Furthermore, DB analysis revealed the presence of HPV 58 in three (10.3\%) hyperplastic specimens, also infected by types 6 and 16 .

NISH confirmed the presence of HPV DNA in the 34 samples found to be positive by the first step of the NPCR assay. On the contrary, none of the 14 samples that were shown to be infected by the second step of NPCR were positive by NISH. This suggests that the number of viral copies in the latter specimens was lower than the detection limit of NISH (10 to 20 copies per cell) $(55,58)$. The physical status of the virus was evaluated before the tyramide amplification step. Granular (type 2) NISH signals, indicative of viral integration into the host genome, were obtained in lesions infected by highrisk viral types (56) (Fig. 3A, C). However, diffuse (type 1) signals were observed for low-risk types, suggesting an episomal HPV presence in infected cells (Fig. 3B).

In relation to further clinicopathologic features of the analyzed group of patients, statistical analysis revealed no correlation between HPV infection and gender $(P=.31)$, age $(P=.49)$, or smoking $(P=.14)$. It is interesting that the percentage of HPV infection (90.6\%) exceeded by far that of smoking $(71.7 \%)$.

\section{DISCUSSION}

Reports on HPV involvement in oral carcinogenesis are conflicting, with infection percentages ranging from 0 to $87 \%$ (Table 1). The observed discrepancies are not fully justifiable by the epidemiologic differences of the examined patient groups or the selective investigation of certain types of oral proliferative conditions, but they may be attributed to the varying sensitivity of the applied methodologies.

To exclude the methodologic variable, we used a highly sensitive NPCR assay as the basis of our experimental procedure. Amplification was performed by two sets of primers, targeted to the highly conserved $3^{\prime}$ end of the L1 HPV gene, with the combined sensitivity of the first and second step of the assay theoretically reaching one viral copy per $10^{6}$ to $10^{7}$ cells $(48,50)$. We have analyzed a series of oral lesions representing the whole histologic spectrum of potentially neoplastic and neoplastic conditions, along with 16 oral samples derived from healthy individuals.

The infection percentage that we detected exceeds $90 \%$ in pathologic cases and is the highest ever reported. None of the examined normal samples were found to be positive, which lies in accordance with some studies $(18,23,26,29,32)$. However, other groups have observed a surprisingly high infection percentage in normal mucosa $(3,11$, $16,41)$, possibly because they analyzed normal tissues that were adjacent to neoplastic lesions. In patients who had proliferative disorders, HPV positivity exceeded the percentage of smoking $(71.7 \%)$, which is considered a major risk factor for oral carcinogenesis (3). Most studies agree that there is no statistically significant correlation between HPV prevalence and smoking history, although it seems that both tobacco and HPV infection may participate in the tumorigenic process in oral mucosa (13, $29,34,38,43$ ).

That the majority of positive lesions (70.8\%) were revealed after the first PCR reaction is indicative of a high viral load and supports the biologic significance of our findings. In comparison to the literature, we have observed the highest infection percentages in every pathologic stage, although comparable infection percentages have been reported by others $(10,18,21,33,37,45)$. This finding suggests that the virus may be involved in early stages of oral carcinogenesis. As expected by the high prevalence of HPV in our patient group, no correlation was established between viral presence and other clinicopathologic characteristics (age, gender, and cancer differentiation). Such associations have been reported by some groups $(13,15$, 38) but could not be confirmed by others (34, 43, 59). In addition, anatomic site seems to be an important factor that determines the susceptibility of squamous epithelium to HPV transformation, with the tonsillar region being more sensitive $(13,15,22$, 35). It is noteworthy that we observed such a high infection rate despite that no tonsillar carcinomas were included in our series of tissues.

TS-PCR revealed the presence of at least one high-risk type in 47 (98.1\%) infected specimens. All infected samples identified by NPCR were also pos- 
itive by TS-PCR, which suggests that the number of viral DNA copies was consistently higher than one per $10^{3}$ cells (48). In accordance with the literature, the prevailing viral type was HPV 16, which was detected in $70.8 \%$ of positive samples, either in single infections $(50.0 \%)$ or in coinfections $(20.8 \%)$. Single HPV 16 and HPV 18 infections were confirmed by RFLP analysis. More than one high-risk type was co-detected in 11 (22.9\%) specimens, whereas low-high-risk coinfections were observed in $6(12.6 \%)$ cases. Both patterns of coinfection have been reported (Table 1). High-high-risk HPV infections may represent a synergistic oncogenic effect of the coinfecting types. Conversely, the low-highrisk infection pattern may be indicative of an incidental colonization of oral mucosa by the low-risk viral type and, hence, a solitary tumorigenic action of the high-risk type (9). Results of HPV positivity and typing in infected specimens were confirmed by DB. In addition, the presence of HPV 58 was detected by a specific probe in three (10.3\%) hyperplastic lesions, always in combination with HPV 6 and 16. This is the first report of oral infection by this high-risk type.

In situ hybridization detected HPV DNA in all infected specimens that were identified by the first step of NPCR, suggesting a high viral load in these samples (56). NISH has generated signals that were characterized as punctate (type 2) in high-risk infections, whereas diffuse (type 1) signals were observed for low-risk types. Type 1 and 2 signals have been associated with the integrative and episomal pattern of HPV infection, respectively (60). Because biotinyl-tyramide enhancement sometimes renders this interpretation deceptive, the physical status of the virus was evaluated before signal amplification. In organs such as the larynx and the cervix, highrisk HPV infection is usually accompanied by viral integration into the host genome (7). It has been postulated that this integration is a critical event in the development of a malignant phenotype, because it allows persistent expression of E6 and E7 HPV genes. However, transcripts of these genes are detectable in episomal high-risk infection of oral keratinocytes in vitro, suggesting that viral integration is not essential for their expression (4). E6 protein binds to $p 53$ and induces its degradation, whereas E7 binds to $\mathrm{pRb}$ and prevents its downstream activity. Functional deregulation of these vital cell growth regulators results in uncontrolled DNA replication and apoptotic impairment, which merely explains the increased oncogenic ability of high-risk types $(7,61)$.

In conclusion, the absence of HPV in normal samples, along with the high frequency of high-risk HPV types in the examined pathologic specimens, suggests an association of the virus with oral carcinogenesis. Furthermore, the high infection per- centage in hyperplasias and dysplasias is indicative of an early involvement of HPV in oral neoplasia.

Acknowledgment: The authors thank Maria Koi for technical assistance.

\section{REFERENCES}

1. Landis SH, Murray T, Bolden S, Wingo PA. Cancer statistics. CA Cancer J Clin 1998;48:6-29.

2. Johnson NW. A global view of the epidemiology of oral cancer. Cambridge, UK: Cambridge University Press; 1991. p. 3-26.

3. D'Costa J, Saranath D, Dedhia P, Sanghvi V, Mehta AR. Detection of HPV-16 genome in human oral cancers and potentially malignant lesions from India. Oral Oncol 1998; 34:413-20.

4. Sugerman PB, Shillitoe EJ. The high risk human papillomaviruses and oral cancer: evidence for and against a causal relationship. Oral Dis 1997;3:130-47.

5. Atula T, Grenman R, Klemi P, Syrjanen S. Human papillomavirus, Epstein-Barr virus, human herpesvirus 8 and human cytomegalovirus involvement in salivary gland tumours. Oral Oncol 1998;391-5.

6. Vasudevan DM, Vijayakumar T. Viruses in human oral cancers. J Exp Cancer Res 1998;17:27-31.

7. zur Hausen H. Papillomavirus infection-a major cause of human cancers. Biochim Biophys Acta 1996;1288:55-78.

8. Premoli-De-Percoco G, Ramirez JL, Galindo I. Correlation between HPV types associated with oral squamous cell carcinoma and cervicovaginal cytology. Oral Surg Oral Med Oral Pathol 1998;86:77-81.

9. Gorgoulis VG, Zaharatos P, Kotsinas A, Kyroudi A, Rassidakis AN, Ikonomopoulos JA, et al. Human papilloma virus (HPV) is possibly involved in laryngeal but not in lung carcinogenesis. Hum Pathol 1998;30(3):274-83.

10. Holladay EB, Gerald WL. Viral gene detection in oral neoplasms using the polymerase chain reaction. Am J Clin Pathol 1993;100(1):36-40.

11. Woods KV, Shillitoe EJ, Spitz MR, Schantz SP, Adler-Storthz K. Analysis of human papillomavirus DNA in oral squamous cell carcinomas. J Oral Pathol Med 1993;22(3):101-8.

12. Brandwein M, Ziittlin J, Nuovo GJ, MacConnell P, Bodian C, Urken M, et al. HPV detection using "hot start" polymerase chain reaction in patients with oral cancer: a clinicopathological study of 64 patients. Mod Pathol 1994;7:720-7.

13. Paz BJ, Cook N, Odom-Maryon T, Xie Y, Wilczynski SP. Human papillomavirus (HPV) in head and neck cancer. Cancer 1997;79(3):595-604.

14. Portugal LG, Goldenberg JD, Wenig BL, Ferrer KT, Nodzenski E, Sabnani JB, et al. Human papillomavirus expression and p53 gene mutations in squamous cell carcinoma. Arch Otolaryngol Head Neck Surg 1997;123:1230-4.

15. Wilczynski SP, Lin BT, Xie Y, Paz IB. Detection of human papillomavirus DNA and oncoprotein overexpression are associated with distinct morphological patterns of tonsillar squamous cell carcinoma. Am J Pathol 1998;152(1):145-56.

16. Miguel RE, Villa LL, Cordeiro AC, Prado JC, Sobrinho JS, Kowalski LP. Low prevalence of human papillomavirus in a geographic region with a high incidence of head and neck cancer. Am J Surg 1998;176(5):428-9.

17. Van Rensburg EJ, van Heerden WF, Venter EH, Raubenheimer EJ. Detection of human papillomavirus DNA with in situ hybridisation in oral squamous carcinoma in a rural black population. S Afr Med J 1995;85:894-6.

18. Chang KW, Chang CS, Lai KS, Chou MJ, Choo KB. High prevalence of human papilloma virus infection and possible 
association with betel quid chewing and smoking in oral epidermoid carcinomas in Taiwan. J Med Virol 1989;28:5761.

19. Heinzel PA, Balaram P, Bernard HU. Mutations and polymorphisms in the p53, p21 and p16 genes in oral carcinomas of Indian betel quit chewers. Int J Cancer 1996;68:420-3.

20. Chatterjee R, Mukhopadhyay D, Chakraborty RN, Basu Mitra R. Evaluation of argyrophilic nucleolar organizer regions (AgNORs) in oral carcinomas in relation to human papillomavirus infection and cytokinetics. J Oral Pathol Med 1997; 26:310-4.

21. Wen S, Tsuji T, Li X, Mizugaki Y, Hayatsu Y, Shinozaki F. Detection and analysis of human papillomavirus 16 and 18 homologous DNA sequences in oral lesions. Anticancer Res 1997;17:307-12.

22. Mineta H, Ogino T, Amano HM, Ohkawa Y, Araki K, Takebayashi S, et al. Human papilloma virus (HPV) type 16 and 18 detected in head and neck squamous cell carcinoma. Anticancer Res 1998;18(6b):4765-8.

23. Nishioka S, Fukushima K, Nishizaki K, Gunduz M, Tominaga $\mathrm{S}$, Fukazawa M, et al. Human papillomavirus as a risk factor for head and neck cancers: a case-control study. Acta Otolaryngol 1999;(Suppl 450):77-80.

24. Koh JY, Cho NP, Kong G, Lee JD, Yoon K. p53 mutations and human papillomavirus DNA in oral squamous cell carcinoma: correlation with apoptosis. Br J Cancer 1998;78: $354-9$.

25. Cerovac Z, Sarcevic B, Kralj Z, Ban J. Detection of human papillomavirus (HPV) type 6, 16 and 18 in head and neck squamous cell carcinomas by in situ hybridization. Neoplasma 1996;43(3):185-94.

26. Eike A, Buchwald C, Rolighed J, Lindeberg H. Human papillomavirus (HPV) is rarely present in normal oral and nasal mucosa. Clin Otolaryngol 1995;20(2):171-3.

27. Syrjanen K, Syrjanen S, Lamberg M, Pyrhonen S, Nuutinen J. Morphological and immunohistochemical evidence suggesting human papillomavirus (HPV) involvement in oral squamous cell carcinogenesis. Int J Oral Surg 1983;12:418-24.

28. Atula S, Auvinen E, Grenman R, Syrjanen S. Human papillomavirus and Epstein-Barr virus in epithelial carcinomas of the head and neck region. Anticancer Res 1997;17(6D):442733.

29. Fouret P, Martin F, Flahault A, Saint-Guily JL. Human papillomavirus infection in the malignant and premalignant head and neck epithelium. Diagn Mol Pathol 1995;4(2): 122-7.

30. Gassenmaier A, Hornstein OP. Presence of human papillomavirus DNA in benign and precancerous oral leukoplakias and squamous cell carcinomas. Dermatologica 1988;176: 224-33.

31. Honig JF. Non radioactive in situ hybridization for detection of human papilloma virus DNA in squamous cell carcinoma of tongue. Bull Group Int Rech Sci Stomatol Odontol 1992; 35(3-4):107-15.

32. Ostwald C, Muller P, Barten M, Rutsatz K, Sonnenburg M, Milde-Langosch K, et al. Human papillomavirus DNA in oral squamous cell carcinomas and normal mucosa. J Oral Pathol Med 1994;23(5):220-5.

33. Arndt O, Johannes A, Zeise K, Brock J. High-risk HPV types in oral and laryngeal papilloma and leukoplakia. Laryngorhinootologie 1997;76(3):142-9.

34. Riethdorf S, Friedrich RE, Ostwald C, Barten M, Gogacz P, Gundlach KK, et al. p53 gene mutations and HPV infection in primary head and neck squamous cell carcinomas do not correlate with overall survival: a long-term follow-up study. J Oral Pathol Med 1997;26(7):315-21.

35. Andl T, Kahn T, Pfuhl A, Nicola T, Erber R, Conradt C, et al. Etiological involvement of oncogenic human papillomavirus in tonsillar squamous cell carcinomas lacking retinoblastoma cell cycle control. Cancer Res 1998;58(1):5-13.

36. Lambropoulos AF, Dimitrakopoulos J, Frangoulides E, Katopodi R, Kotsis A, Karakasis D. Incidence of human papillomavirus 6, 11, 16, 18 and 33 in normal oral mucosa of a Greek population. Eur J Oral Sci 1997;105(4):294-7.

37. Lo Muzio L, Mignogna MD, Staibano S, de Vico G, Salvatore G, Damiano S, et al. Morphometric study of nucleolar organiser regions (AgNOR) in HPV-associated precancerous lesions and microinvasive carcinoma of the oral cavity. Oral Oncol 1997;33:247-59.

38. Cruz IBF, Snijders PJF, Steenbergen RDM, Meijer CJLM, Snow GB, Walboomers JMM, et al. Age-dependence of human papillomavirus DNA presence in oral squamous cell carcinomas. Oral Oncol Eur J Cancer 1996;32B:55-62.

39. Snijders PJ, Scholes AG, Hart CA, Jones AS, Vaughan ED, Woolgar JA, et al. Prevalence of mucosotropic human papillomavirus in squamous-cell carcinoma of the head and neck. Int J Cancer 1996;66(4):464-9.

40. Matzow T, Boysen M, Kalantari M, Johansson B, Hagmar B. Low detection rate of HPV in oral and laryngeal carcinomas. Acta Oncol 1998;37:73-6.

41. Adams V, Schmid S, Zariwala M, Schmid M, Kleihues P, Briner J, et al. Prevalence of human papilloma virus DNA in head and neck cancers carrying wild-type or mutant p53 tumor suppressor genes. Anticancer Res 1999;19(1A):1-6.

42. Jalal H, Sanders CM, Prime SS, Scully C, Maitland NJ. Detection of human papilloma virus type 16 DNA in oral squames from normal young adults. J Oral Pathol Med 1992; 21(10):465-70.

43. Scholes AG, Liloglou T, Snijders PJ, Hart CA, Jones AS, Woolgar JA, et al. p53 mutations in relation to human papillomavirus type 16 infection in squamous cell carcinomas of the head and neck. Int J Cancer 1997;71(5):796-9.

44. Elamin F, Steingrimsdottir H, Wanakulasuriya S, Johnson N, Tavassoli M. Prevalence of human papillomavirus infection in premalignant and malignant lesions of the oral cavity in U.K. subjects: a novel method of detection. Oral Oncol 1998; 34:191-7.

45. Penhallow J, Steingrimsdottir H, Elamin F, Warnakulasuriya S, Farzaneh F, Hohnson N, et al. p53 alterations and HPV infections are common in oral SCC: p53 gene mutations correlate with the absence of HPV 16-E6 DNA. Int J Dermatol 1998;12:59-68.

46. Pindborg JJ, Reichart PA, Smith CJ, van der Waal I. Histological typing of cancer and precancer of the oral mucosa. 2nd ed. Heidelberg, Springer; 1997.

47. Resnick RM, Cornelissen MT, Wright DK, Eichiinger Gh, Fox HS, ter Schegget J, et al. Detection and typing of human papillomavirus in archival cervical cancer specimens by DNA amplification with consensus primers. J Natl Cancer Inst 1990;82:1477-84.

48. Schiffman MH, Bauer HM, Lorincz AT, Manos MM, Byrne JC, Glass AG, et al. Comparison of Southern blot hybridisation and polymerase chain reaction methods for the detection of human papillomavirus DNA. J Clin Microbiol 1991; 29:573-7.

49. Van den Brule AJ, Snijder PJ, Gordijn RL, Bleker OP, Meijer CJ, Walboomers JM. General primer-mediated polymerase chain reaction permits the detection of sequenced and still unsequenced human papillomavirus genotypes in cervical scrapes and carcinomas. Int J Cancer 1990;45:644-9.

50. de Husman AMR, Walboomers JMM, van den Brule AJC, Meijer CJLM, Snijders PJF. The use of general primers GP5 and GP6 elongated at their 3' ends with adjacent highly conserved sequences improves human papillomavirus detection by PCR. J Gen Virol 1995;76:1057-62.

51. Lungu O, Wright TC, Silverstein S. Typing of human papilloma virus by polymerase chain reaction amplification with 
L1 consensus primers and RFLP analysis. Mol Cell Probes 1992;6:145-52.

52. Jacobs MV, de Roda Husman AM, van den Brule AJC, Snijders PJF, Meijer CJLM, Walboomers JMM. Groupspecific differentiation between high and low-risk human papillomavirus genotypes by general primer-mediated PCR and two cocktails of oligonucleotide probes. J Clin Microbiol 1996;33:901-5.

53. Jacobs MV, Snijders PJF, van den Brule AJC, Helmerhorst TJM, Meijer CJLM, Walboomers JMM. A general primer GP5+/GP6 + mediated PCR enzyme immunoassay method for rapid detection of 14 high-risk and 6 low-risk human papillomavirus genotypes in cervical scrapings. J Clin Microbiol 1997;35:791-5.

54. Matsukura T, Sugase M. Molecular cloning of a novel human papillomavirus (type 58) from an invasive cervical carcinoma. Virology 1990;177:833-6.

55. Gorgoulis V, Giatromanolaki A, Karameris A, Tsatsanis C, Aninos D, Ozanne B, et al. Epidermal growth factor receptor expression in squamous cell lung carcinomas: an immunohistochemical and gene analysis in formalin-fixed, paraffinembedded material. Virchows Arch A Pathol Anat 1993;423: 295-302.
56. Herrington CS, McGee JO. Diagnostic molecular pathology. A practical approach. Vol. 2, IRL. Oxford: Oxford University Press; 1992. p. 87.

57. Herrington CS, Burns J, Graham AK, Bhatt B, McGee JO'D. Interphase cytogenetics using biotin and digoxigenin labelled probes: I. Relative sensitivity of both reporter molecules for the detection of HPV 16 in CaSki cells. J Clin Pathol 1989;42:591-600.

58. Park JS, Namkoong SE, Lee HY, Kim SJ, Daniel RW, Shah KV. Detection of human papillomavirus genotypes in cervical neoplasia from Korean women using polymerase chain reaction. Gynecol Oncol 1991;41:129-34.

59. Fouret P, Monceaux G, Temam S, Lacourreye L, Saint-Guily JL. Human papillomavirus in head and neck squamous cell carcinomas in nonsmokers. Arch Otolaryngol Head Neck Surg 1997;123:513-6.

60. Cooper K, Herrington CS, Graham AK, Evans MF, McGee JO. In situ evidence for HPV 16, 18, 33 integration in cervical squamous cell cancer in Britain and South Africa. J Clin Pathol 1991;44:406-9.

61. Liu X, Han S, Baluda MA, Park NH. HPV-16 oncogenes E6 and E7 are mutagenic in normal human oral keratinocytes. Oncogene 1997;14:2347-53.

\section{Book Review}

\section{Rapley R, editor: The Nucleic Acid Protocols Handbook, 1050 pp, Totowa, NJ, Humana Press, 2000 (\$110).}

This book contains 120 standard protocols for analyzing nucleic acids. It is divided into 10 parts, including nucleic acid extraction, probe design and synthesis, gene library construction and screening, DNA sequencing, polymerase chain reaction, and techniques for inducing and identifying mutations and for localizing genes. Almost all chapters contain references to Maniatis's 1989 spiral-bound volumes, indicating that the present book is in essence a practice-tested version of that classical laboratory manual. Most protocols refer to widely used techniques, the description of which could be found, in one form or another, in many other manuals or research papers. The advantage to the potential user is that the techniques are presented in minute details and in a "cookbook-standardized manner." That most contributors are from England or Europe should not discourage anyone because the themes covered are universal. The personal notes inserted by each contributor provide assurance that the techniques would work in any laboratory, as long as the instructions are followed carefully. Having all of those protocols updated and tested in practice and bound in one volume will be attractive to many scientists who deal with molecular biology techniques.

\author{
Hazem M. Hallak \\ Thomas Jefferson University \\ Philadelphia, Pennsylvania
}

